\title{
A Study on the Impact of Social Media on Consumer Buying Behaviour of Mobile Phones in Chennai
}

\section{OPEN ACCESS}

Manuscript ID:

MGT-2021-08033574

Volume: 8

Issue: 3

Month: January

Year: 2021

P-ISSN: 2321-4643

E-ISSN: 2581-9402

Received: 18.10 .2020

Accepted: 29.11.2020

Published: 01.01.2021

Citation:

Gajashree, S., and J. Anand. "A Study on the Impact of Social Media on Consumer Buying Behaviour of Mobile Phones in Chennai." Shanlax International Journal of Management, vol. 8, no. 3, 2021, pp. 54-59.

DOI:

https://doi.org/10.34293/ management.v8i3.3574

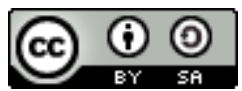

This work is licensed under a Creative Commons Attribution-ShareAlike 4.0 International License.

\author{
S. Gajashree \\ Department of Management Studies \\ SRM Valliammai Engineering College, Chennai, Tamil Nadu, India
}

\section{J. Anand}

Assistant Professor, Department of Management Studies

SRM Valliammai Engineering College, Chennai, Tamil Nadu, India

\begin{abstract}
This paper aims to investigate the impact of social media on consumer buying behavior. The primary purpose of this research is to identify the effect of social media on consumer buying decisions. Social Media have given many opportunities to consumers in adapting to different aspects of life. Facebook, Twitter and Instagram have played significant roles in expanding consumer's online purchases. This paper aims to know which consumers are mostly influenced by the online purchase of mobile through social media and the kinds of social media that are employed mainly by consumers in Chennai. The research carried out primary research methods and questionnaire to investigate the impact of social media sites on the user's changing behavior who aim to purchase online. The target of the research is to elucidate why, when, and the way social media has impacted on the consumer decision process. The theoretical framework rests on the literature of the consumer decision-making process, social media, and previous studies relating to social media marketing. The quantitative research method is tailored to the aim of this research. The empirical data was gathered by sending out an opinion poll to individuals. The study explains how individuals are attending processing and selecting the knowledge on social media before a sale. The findings indicate that individuals pursue an active role in information search on social media comparing to mass media. Yet, information exposure is selective and subjective during knowledge search. Results show that social media usage influences consumer satisfaction within the stages of data search and alternative evaluation, with happiness getting amplified. The consumer moves along the method towards the ultimate purchase decision and post-purchase evaluation.
\end{abstract}

Keywords: Social media, Consumer, Buying behaviour, Marketing, Online opportunities, Mobile phone, Decision, Perception

\section{Introduction}

This paper covers the impact of social media on consumer behavior of mobile phone purchases. Social media is that the online communications medium dedicated to community-based input, interaction, and contentsharing. Social media marketing features a brought a dramatic change in marketing tools because the social media user isn't only an observer but also act as a lively participant because he gives input, reviews and opinion on the open platform. Social media helps to find unique discounts and promotions for mobile phones. The mobile phone has become an integral part of human daily and personal communication across the globe. Social media to find out about new mobile phones and specific stores of mobiles. According to a current report, the number of social media client worldwide in 2019 is 3.484 billion. As more and more people joining social media. The most crucial role of social media has changed the way of how consumers and marketers communicate. 
Also, Social media can play a huge role in influencing consumers in their purchases of mobile phones. Social media usage affects consumer satisfaction within the stages of data search. Moreover, by using social media, consumers can influence other buyers through reviews of mobile phones used. The goal of this paper is to find the impact of social media on consumer purchase behavior of mobile phones. Among the many parameters in a social media impact of consumer buying behavior of mobile purchasing decision three main parameters have been considered in this research, namely reviews of different buyers, company or brand presentation on social networks and the difficulties of information search for mobile phone through social media. A quantitative survey was wont to retroactively plan to explore aspects of the phases within the decision process. A total of 50 participants completed the study, and their responses were used to analyze the decision-making process of their impact of social media on mobile purchase instances.

\section{Review of Literature}

According to McKinsey Company (2010) In his study, Social Media features a notable influence on customers, mainly who are first-time purchasers of a product. It's a more significant influence on high priced products because the consumers want to conduct additional analysis and to urge opinions for purchasing the merchandise. This means that Social Media has an impression on customers in their data search stage of shopping for a product. As a result, customers will use Social Media to urge data concerning the product and services. Xia wang, Case Study of Lagos State University Students (2018) The examination researches peer correspondence through internet based life sites; singular level tie quality. Study information 292 members who occupied with peer correspondence about through online networking. Ionas Elisabeta; Ivona Stioca (2014) The paper manages the effect of online networking on purchaser behavior. The conclusions are built up as far because of the univariate and bivariate investigation. The investigation incorporates a shopper profile that utilizations interpersonal organizations. Abhinav (2014) The examination endeavors to differentiate the part and therefore, the effect of web-based life on a buyer purchasing choice. The exploration clarifies how people are choosing the info via web-based networking media before a buy. Ethel Lee (2014) The goal of the investigation is to explain why, when, and the way internet based life has affected on shopper choice process.

\section{Problem Statement}

The purpose of the study was to identify the Social media usage influences consumer satisfaction. Moreover, this study aims to answers the subsequent questions precisely:

- What is the purpose of using social media?

- How social media impact on purchasing decision of consumers on mobile phones?

- Make a comparison between males and females on how social media impact on their buying?

\section{Objectives}

Primary Objectives: A Study on the impact of social media on consumer buying behavior of mobile phones in Chennai.

Secondary Objectives: To identify the factors, influence the consumers to purchase mobile phones through social media. To find out which is the best social media preferred by the consumer. To evaluate the various channels prepared by a consumer for buying decisions over traditional channels.

\section{Research Methodology}

The most important thing that has to understand that Research methodology is a system to solve the related problem. It is not only science but also art the way to do research scientifically. It's the logic to be utilized in the context of research. The researcher has got to understand the matter, which provides him the direction the way to solve the issue. The research methodology consists of a series of actions or steps necessary to carry out research work effectively.

\section{Research Design}

"A research design is that the arrangement of conditions for collection and analysis of data during a fashion that aims to combine relevance to the research purpose with economy in procedure" Research design is that the framework of research methods and techniques chosen by a researcher. The 
planning allows researchers to hone in on research methods suitable for the topic matter and found out their studies up for fulfillment. Here the descriptive research design is employed.

\section{Descriptive Research}

Descriptive research aims to correctly and systematically explain a population, situation, or phenomenon. It can answer what, when, where, when and how questions, but not why questions. Descriptive research is designed to describe something, such as demographical characteristics of consumers who use the products. It deals with determining the frequency with which something occurs or how two variables vary together. A descriptive research design can use a wide variety of research methods to investigate one or more variables. Unlike in experimental research, the researcher doesn't control or manipulate any of the variables but only observes and measures them.

\section{Sampling Design}

Sampling is done to collect samples - the sampling techniques used for large numbers. The sampling techniques used in this study are convenience sampling under non-probability. In non-probability selection, the present chance of any particular unit in the population being into the sample is unknown. In convenience sampling, the samples from the population are chosen primarily based on the convenience of the researcher.

\section{Sampling Size}

The survey is going to be conducted on the idea of the sampling method. The study was conducted on Mobile Phone users. The researcher will develop sample design; the researcher will be collecting the information from 55 customers who were selected for the present study in Chennai city.

\section{Survey Questionnaire Method}

A survey questionnaire is a type of data gathering method utilized to collect, analyze, and interpret the different views of a group of people from a particular population. The survey questionnaire has been used in different fields like research, marketing, political opinions, psychology, etc.

\section{Questionnaire}

The questionnaire is an instrument for research, which consists of an inventory of questions, alongside the selection of answers, printed or typed during a sequence on a form used for acquiring specific information from the respondents. Generally, questionnaires are delivered to the persons concerned either by post or mail, requesting them to answer the questions and return them.

\section{Methods of Data Collection}

Primary Data: Primary data is known as firsthand information to determine a specific problem. Primary data is collected from its primary sources, i.e., the source of its origin, where the info is generated. It's the first time organized by its investigator for statistical analysis.

Secondary Data: Secondary data are the data are in actual existence, in records, having been already collected and also treated statistically. In short, it is the data that has been already assembled, presented, tabulated, and located with analytical that have been collected by some agencies, government department and research workers are often obtained from records, books, government publications and journals. Utmost care has taken by the researcher while collecting the info from the varied sources.

\section{Statistical Design}

The statistical design of a web controlled experiment (a.k.a A/B test) is that the results of the interpretation of a substantive business question of interest into an investigation with a well-defined statistical model that permits the utilization of knowledge during a decision-making process within the presence of uncertainty. The planning should fully describe the experiment in terms of the choices relevant to its statistical model.

\section{Statistical Tools Used}

For the analysis of the info and its interpretation, various tools of research were used.

\section{Mann Whitney U-Test}

The Mann-Whitney U test compares the number of times a score from one sample is ranked above a score from another piece. Once the info is organized, calculations are going to be administered on the 
ranks. Given the nonparametric nature of this statistical analysis, there are fewer assumptions to assess. In statistics, the Mann-Whitney U test may be a nonparametric test of the null hypothesis that, for randomly selected values $\mathrm{X}$ and $\mathrm{Y}$ from two populations, the probability of $\mathrm{X}$ being more significant than $\mathrm{Y}$ is adequate the possibility of $\mathrm{Y}$ being more significant than $\mathrm{X}$.

\begin{tabular}{|c|c|c|c|c|}
\hline \multicolumn{5}{|c|}{ Ranks } \\
\hline & $\begin{array}{l}\text { Social media } \\
\text { purchase }\end{array}$ & $\mathrm{N}$ & $\begin{array}{l}\text { Mean } \\
\text { Rank }\end{array}$ & $\begin{array}{l}\text { Sum of } \\
\text { Ranks }\end{array}$ \\
\hline \multirow{3}{*}{ Values } & $\begin{array}{l}\text { Triggers to } \\
\text { Purchase Mobile }\end{array}$ & 55 & 58.00 & 3190.00 \\
\hline & $\begin{array}{l}\text { Change Attitude for } \\
\text { Mobile Purchase }\end{array}$ & 55 & 53.00 & 2915.00 \\
\hline & Total & 110 & & \\
\hline
\end{tabular}

\begin{tabular}{|l|c|}
\hline \multicolumn{2}{|c|}{ Test Statistics $^{\mathbf{a}}$} \\
\hline Mann-Whitney U & Values \\
\hline Wilcoxon W & 1375.000 \\
\hline Z & 2915.000 \\
\hline Asymp. Sig. (2-tailed) & -.992 \\
\hline \multicolumn{2}{|l|}{ a. Grouping Variable: Social media purchase } \\
\hline
\end{tabular}

Interpretation: From the above table, P-value (0.321) is more significant than LOS $(0.05), \mathrm{H} 0$ is accepted. Therefore, Social media change people's attitude for mobile purchase but does not trigger the people for mobile investment.

\section{Chart 1: Profile of Respondents}

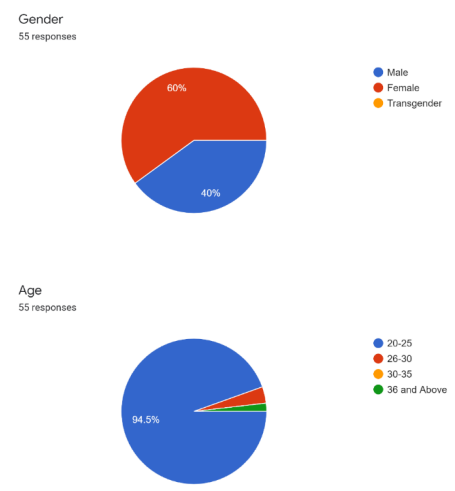

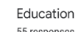

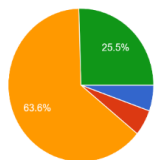

- Diploma Graduad

From chart one, we analyze. According to Gender, the majority of respondents are female $(60 \%)$. According to Age, the majority of respondents are 20-25(94.5). According to Educational qualifications the majority of respondents are graduates $(63.6 \%)$.

Table 1: Classification of Social Media Site is Likely to buy Mobile Phones

\begin{tabular}{|c|l|c|c|}
\hline $\begin{array}{c}\text { S. } \\
\text { No. }\end{array}$ & Particulars & $\begin{array}{c}\text { No. of } \\
\text { Respondents }\end{array}$ & Percentage \\
\hline 1 & Facebook & 6 & $10.9 \%$ \\
\hline 2 & Instagram & 20 & $36.4 \%$ \\
\hline 3 & WhatsApp & 10 & $18.2 \%$ \\
\hline 4 & Others & 19 & $34.5 \%$ \\
\hline \multicolumn{2}{|c|}{ Total } & 55 & $100 \%$ \\
\hline
\end{tabular}

Inference: From the above table, it is inferred that $36.4 \%$ of respondents liked to buy the mobile on Instagram.

Table 2: Classification of Social Media Trigger to Purchase a Mobile Phone

\begin{tabular}{|c|c|c|c|}
\hline $\begin{array}{c}\text { S. } \\
\text { No. }\end{array}$ & Particulars & $\begin{array}{c}\text { No. of } \\
\text { Respondents }\end{array}$ & Percentage \\
\hline 1 & Yes & 33 & $60 \%$ \\
\hline 2 & No & 22 & $40 \%$ \\
\hline \multicolumn{2}{|c|}{ Total } & 55 & $100 \%$ \\
\hline
\end{tabular}

Inference: From the above table, it is inferred that $60 \%$ of Respondents said social media triggers a mobile phone.

Table 3: Classification of Social Media Influence Mobile buying Decision

\begin{tabular}{|c|c|c|c|}
\hline S. No. & Particulars & $\begin{array}{c}\text { No. of } \\
\text { Respondents }\end{array}$ & Percentage \\
\hline 1 & Yes & 33 & $60 \%$ \\
\hline 2 & No & 22 & $40 \%$ \\
\hline \multicolumn{2}{|c|}{ Total } & 55 & $100 \%$ \\
\hline
\end{tabular}

Inference: From the above table, it is inferred that $60 \%$ of respondents said that social media influence the mobile buying decision. 
International Journal of Management

Table 4: Classification of Social Media Advertisements Influence to Try a new Mobile Brand

\begin{tabular}{|c|l|c|c|}
\hline $\begin{array}{c}\text { S. } \\
\text { No }\end{array}$ & \multicolumn{1}{|c|}{ Particulars } & $\begin{array}{c}\text { No. of } \\
\text { Respondents }\end{array}$ & Percentage \\
\hline 1 & Strongly Agree & 6 & $10.9 \%$ \\
\hline 2 & Agree & 15 & $27.3 \%$ \\
\hline 3 & Neutral & 24 & $43.6 \%$ \\
\hline 4 & Disagree & 6 & $10.9 \%$ \\
\hline 5 & Strongly Disagree & 4 & $7.3 \%$ \\
\hline \multicolumn{2}{|c|}{ Total } & 55 & $100 \%$ \\
\hline
\end{tabular}

Inference: From the above table, it is inferred that $43.6 \%$ of Respondents' decision is neutral for social media advertisements influence to try new mobile phone brand.

Table 5: Classification of the Attitude Towards a Positive Comment about New Brands of Mobile

\begin{tabular}{|c|c|c|c|}
\hline S. No. & Particulars & $\begin{array}{c}\text { No. of } \\
\text { Respondents }\end{array}$ & Percentage \\
\hline 1 & Yes & 38 & $69.1 \%$ \\
\hline 2 & No & 17 & $30.9 \%$ \\
\hline \multicolumn{2}{|c|}{ Total } & 55 & $100 \%$ \\
\hline
\end{tabular}

Inference: From the above table, it is inferred that $69.1 \%$ of respondents said that the positive comments on social media create an attitude towards a particular brand of mobile phones

Table 6: Classification of the Social Network Channels is More Values Marketing Channels than the Traditional Media

\begin{tabular}{|c|l|c|c|}
\hline $\begin{array}{c}\text { S. } \\
\text { No. }\end{array}$ & \multicolumn{1}{|c|}{ Particulars } & $\begin{array}{c}\text { No of } \\
\text { Respondents }\end{array}$ & Percentage \\
\hline 1 & Strongly Agree & 11 & $20 \%$ \\
\hline 2 & Agree & 30 & $54.5 \%$ \\
\hline 3 & Neutral & 8 & $14.5 \%$ \\
\hline 4 & Disagree & 4 & $7.3 \%$ \\
\hline 5 & Strongly Disagree & 2 & $3.6 \%$ \\
\hline \multicolumn{2}{|c|}{ Total } & 55 & $100 \%$ \\
\hline
\end{tabular}

Inference: From the above table, it is inferred that $54.5 \%$ of respondents agreed that the social network channels are more values marketing channels than the traditional ones.
Table 7: Classification of Social Media Sites that Influence Mobile Purchase on the Day to Day life

\begin{tabular}{|c|l|c|c|}
\hline $\begin{array}{c}\text { S. } \\
\text { No. }\end{array}$ & \multicolumn{1}{|c|}{ Particulars } & $\begin{array}{c}\text { No of } \\
\text { Respondents }\end{array}$ & Percentage \\
\hline 1 & Daily & 7 & $12.7 \%$ \\
\hline 2 & $1-2$ times a week & 10 & $18.2 \%$ \\
\hline 3 & $3-4$ times a week & 6 & $10.9 \%$ \\
\hline 4 & Once a month & 10 & $18.2 \%$ \\
\hline 5 & $\begin{array}{l}\text { Only when } \\
\text { needed }\end{array}$ & 22 & $40 \%$ \\
\hline \multicolumn{2}{|c|}{ Total } & 55 & $100 \%$ \\
\hline
\end{tabular}

Inference: From the above table, it is inferred that $40 \%$ of respondents said that social media sites influenced only when they needed time for mobile purchase.

\section{Findings}

- $60 \%$ of respondents are Female.

- $94.5 \%$ of respondents are of the age of 20-25.

- $63.6 \%$ of respondents have completed their graduation.

- $36.4 \%$ of respondents are liked to buy mobile phones on Instagram.

- $45.5 \%$ of the respondents have to search always the information on social media before the mobile purchase.

- $60 \%$ of respondents said that social media trigger to purchase a mobile phone.

- $41.8 \%$ of respondents agreed that social media helps in acquiring information about mobile phones.

- $60 \%$ of respondents said that social media influence mobile buying decisions.

- $43.6 \%$ of Respondents' decision is neutral for social media advertisements influence to try new mobile phone brand.

- $60 \%$ of respondents agreed that social media advertisements influence try new mobile phone brand.

- $69.1 \%$ of respondents said that positive comments on social media create an attitude towards a particular brand of mobile phones.

- $40 \%$ of respondents said that social media sites only influence when they needed time for mobile purchase.

- $54.5 \%$ of respondents agreed that the social 
network channels are a more valuable marketing channel than the traditional ones.

- $52.7 \%$ of respondents agreed that social media is more influential than traditional media in your final purchase.

- $52.7 \%$ of respondents have Likely to buy the mobile online in the future.

\section{Suggestions}

- The marketers should Share valuable and informative content and Engage with the audience.

- The mobile companies which used social media strategies should build their brand authority.

- Social media marketers should overcome the bad reviews and comments with their high-quality, unique content and post videos to drive their reach.

- Having a social media profile and posting random content will not take social media marketers' brand anywhere. Produce engaging content that grabs their audience's eyeballs and further pushes them to like it and share it.

\section{Conclusion}

The research has considered various Social Websites that do the work of Networking that's Facebook, WhatsApp, Twitter, and lots more. The study explains how individuals are attending processing and selecting the knowledge on social media before buying. The findings indicate that individuals pursue an active role in information search on social media comparing to mass media. Yet, information exposure is selective and subjective during knowledge search. Results show that social media usage influences consumer satisfaction within the stages of data search and alternative evaluation, with happiness getting amplified. The consumer moves along the method towards the ultimate purchase decision and post-purchase evaluation.
Results conducted through this study suggest that companies should specialize in being present on social networks, visible on search engines and supply continuous online feedback. Finally, results show companies should specialize in improving their online perception through customer engagement since it's one of the most ways in which customers nowadays decide whether to shop for product or not.

\section{References}

Wanga, Xia, et al. "Social Media Peer Communication and Impacts on Purchase Intentions: A Consumer Socialization Framework." Journal of Interactive Marketing, vol. 26, no. 4, 2012, pp. 198-208.

Ioanăs, Elisabeta, and Ivona Stoica. "Social Media and its Impact on Consumers Behavior." International Journal of Economic Practices and Theories, vol. 4, no. 2, 2014, pp. 295-303.

Hutter, Katja, et al. "The Impact of User Interactions in Social Media on Brand Awareness and Purchase Intention: The Case of MINI on Facebook." Journal of Product \& Brand Management, vol. 22, 2013, pp. 342-351.

Lee, Ethel. Impacts of Social Media on Consumer Behavior - Decision Making Process, Turku University of Applied Sciences, 2013.

Bughlin, Jacques, et al. "A New Way to Measure word-of-mouth Marketing." Mckinsey Quarterly, 2010.

Mamoria, C.B. Personnel Management: (Management of Human Resources), Himalaya Publishing House, 1994.

Malhotra, R.K., et al. Personnel Management, Anmol Publications, 2003.

Tripathi, P.C. Personnel Management and Industrial Relations, Sultan Chand \& Sons, 2013.

Kothari, C.R. Research Methodology: Methods and Techniques, Wishwa Prakashan, 1997.

\section{Author Details}

S. Gajashree, Department of Management Studies, SRM Valliammai Engineering College, Chennai, Tamil Nadu, India

Dr. J. Anand, Assistant Professor, Department of Management Studies, SRM Valliammai Engineering College, Chennai, Tamil Nadu, India, Email ID: anand1087jaya@gmail.com. 